Maryanti, 2016

\title{
ANALISIS PROFITABILITAS, PERTUMBUHAN PERUSAHAAN, PERTUMBUHAN PENJUALAN DAN STRUKTUR AKTIVA TERHADAP STRUKTUR MODAL PADA PERUSAHAAN SEKTOR INDUSTRI BARANG KONSUMSI YANG TERDAFTAR DI BURSA EFEK INDONESIA
}

(Studi Empiris Pada Perusahaan Manufaktur yang Terdaftar di Bursa Efek Indonesia Tahun 2012-2014)

\author{
Eny Maryanti \\ Fakultas Ekonomi dan Bisnis, Universitas Muhammadiyah Sidoarjo \\ Email : eny_maryanti@yahoo.com
}

\begin{abstract}
The purpose of this study was to analyze the profitability, growth, sales growth and asset structure of the company on capital structure. The research object was the entire industrial sector of consumer goods amounted to 36 companies, but based on the completeness of the data, then, only 30 companies takan as samples with the observation period of 2012-2014. The independent variables were profitability, growth, sales growth and asset structure while the dependent variable was capital structure (debt to total assets ratio). The data analysis used multiple linear regressions. These results indicate that the growth of the company have a significant effect on the capital structure. Profitability, sales growth and asset structure has no effect on the capital structure.
\end{abstract}

Key Words : Profitability, Growth of Company, Asset Structure Of The Company, Sales Growth, Capital Structure

\section{Pendahuluan}

Persaingan dalam dunia bisnis semakin ketat, kondisi tersebut mengharuskan perusahaan agar lebih unggul dalam persaingan untuk mencapai tujuan perusahaan. Perusahaan mempunyai tujuan bisa meningkatan kemakmuran para pemegang saham dan mencapai keuntungan yang optimal. Dalam memenuhi tujuan tersebut maka perlu pengambilan keputusan yang tepat dari manajemen perusahaan dalam pengambilan keputusan pendanaan. Keputusan pendanaan keuangan perusahaan berpengaruh terhadap aktivitas perusahaan. Modal dibutuhkan setiap perusahaan, untuk danaoperasional maupun dalam ekspansi perusahaan. Perusahaan harus menentukan besarnya modal yang dibutuhkan untuk memenuhi atau membiayai perusahaan.

Masalah struktur modal merupakan masalah yang sangat penting bagi setiap perusahaan, struktur modal akan mempunyai dampak terhadap posisi keuangan perusahaan.Kesalahan dalam menentukan struktur modal akan berpengaruh terhadap keberlangsungan perusahaan, terutama jika perusahaan terlalu besar dalam menggunakan hutang, maka beban yang harus ditanggung perusahaan semakin besar juga, hal tersebut meningkatkan resiko keuangan perusahaan jika perusahaan tidak bisa membayar beban bunga atau angsuran hutangnya. Menurut Brigham dan Houston (2011:153) “jika perusahaan ingin tumbuh membutuhkan modal, dan modal tersebut dalam bentuk utang dan ekuitas".

"Perusahaan mengutamakan pemenuhan dananya dari dalam perusahaan akan mengurangi ketergantungannya pada pihak luar dan hanya menggunakan modal asing apabila dana yang diperlukan kurang mencukupi. Oleh karena itu, perusahaan perlu memperhatikan penggunaan sumber dananya, karena setiap sumber dana memiliki biaya modal yang berbeda dan tingkat risiko yang berbeda pula" (Amiriyah dan Andayani, 2014)

$$
\text { Binangkit dan Raharjo }
$$
mengemukakan bahwa "semakin besar penggunaan hutang dalam struktur modal perusahaan akan memperbesar pembayaran angsuran dan bunga yang menjadi kewajiban perusahaan dan akan meningkatkan resiko ketidakmampuan cash flow perusahaan untuk memenuhi kewajiban tersebut".

Hal tersebut juga didukung oleh Amiriyah dan Andayani (2014) menyatakan "Semakin besar rasio struktur modal menandakan semakin banyak jumlah pinjaman jangka panjang yang menyebabkan semakin banyak pula bagian dari laba operasi yang 
digunakan untuk membayar beban bunga tetap, dan semakin banyak aliran kas yang digunakan untuk membayar angsuran pinjaman. Hal ini akan mengakibatkan menurunnya jumlah laba bersih sesudah pajak yang akan diperoleh perusahaan.

Brigham dan Houstoun (2011:153) menyatakan pendanaan utang memiliki dua keunggulan penting: (1) bunga yang dibayarkan atas utang dapat menjadi pengurang pajak, sementara deviden yang dibayarkan atas saham bukan pengurang pajak. (2) Pengembalian atas utang jumlahnya tetap, sehingga pemegang saham tidak ikut menerima laba perusahaan jika perusahaan meraih keberhasilan luar biasa.

Perusahaan perlu untuk mempertimbangkan faktor-faktor yang mempengaruhi struktur modal sehingga dapat menetapkan keputusan struktur modal. Selain usaha dalam menciptakan kinerja, perusahaan juga berusaha mencapai pertumbuhan yang tinggi setiap tahunnya. Menurut Fauzi dan Suhadak ( 2015) "Pertumbuhan perusahaan yang tinggi mencerminkan semakin luasnya jangkauan perusahaan". Pertumbuhan perusahaan yang tinggi menunjukkan kinerja perusahaan yang baik, karena terjadi peningkatan terhadap aset atau penjualan perusahaan.

Wald (1999) mengatakan bahwa"struktur modal berhubungan dengan tingkat long term debt I asset ratio, resiko perusahaan, profitabilitas, firm size \& growth." Zuliani dan Asyik (2014) menyatakan bahwa Hasil dari penelitian ini menunjukkan bahwa: " profitabilitas berpengaruh signifikan terhadap struktur modal, pertumbuhan penjualan tidak berpengaruh signifikan terhadap struktur, struktur aset tidak berpengaruh signifikan terhadap struktur modal, dan tingkat pertumbuhan tidak berpengaruh signifikan terhadap struktur modal."

Penelitian Putri (2012) menyatakan bahwa Hasil penelitian ini menyimpulkan "berpengaruh positif dan tidak signifikan terhadap struktur modal ,Struktur Aktiva berpengaruh positif dan signifikan terhadap struktur modal dan Ukuran Perusahaan (SIZE) berpengaruh positif dan signifikan terhadap struktur modal" Sedangkan penelitian Kesuma (2009) menyatakan bahwa "Pertumbuhan penjualan mempunyai pengaruh negatif atau berlawanan arah dengan sturktur modal. Profitabilitas mempunyai pengaruh berlawan arah dengan struktur modal, Rasio
Hutang ,mempunyai pengaruh yang signifikan dan searah dengan struktur modal."

Banyak penelitian yang telah menganalisis berbagai pengaruh faktor terhadap struktur modal, akan tetapi hasil dari penelitian-penelitian tersebut belum menunjukkan hasil yang konsisten. Berdasarkan penelitian tersebut, maka peneliti bertujuan memilih faktor-faktor yang dianggap dominan dalam mempengaruhi perilaku struktur modal. Faktor-faktor yang akan diangkat dalam penelitian ini untuk meneliti pengaruh struktur modal terhadap faktor-faktor tersebut antara lain: Profitabilitas, Pertumbuhan perusahaan, pertumbuhan penjualan dan struktur asset

Berdasarkan latar belakang diatas maka penulis tertarik ingin meneliti mengenai "Pengaruh Profitabilitas, Pertumbuhan perusahaan, pertumbuhan penjualan dan struktur asset terhadap struktur modal pada perusahaan sektor industri barang Konsumsi yang Terdaftar di Bursa Efek Indonesia (BEI).

\section{Kajian Pustaka dan Pengembangan Hipotesis Struktur Modal}

Struktur modal adalah pembelanjaan permanen didalam mencerminkan perimbangan antara hutang jangka panjang dengan modal sendiri (Binangkit dan Raharjo, 2014). Menurut Riyanto (2001) Struktur modal didefinisikan sebagai perimbangan atau perbandingan antara jumlah hutang jangka panjang dengan modal sendiri .

\section{Teori Pecking Order}

Perusahaan dapat menggunakan keputusan pendanaan menggunakan laba ditahan atau menggunakan hutang. Teori pecking order merupakan teori yang memberikan gambaran bahwa perusahaan lebih mengutamakan laba ditahan, hutang dan penerbitan saham sebagai pilihan terakhir.(Fauzi dan Suhadak, 2015).

\section{Teori Tradeoff}

Teori tradeoff struktur modal menunjukkan bahwa hutang bermanfaat bagi perusahaan karena bunga dapat dikurangi dalam penghitungan pajak, tetapi hutang juga menimbulkan biaya yang berhubungan dengan kebangkrutan yang aktual dan potensial. Struktur modal yang optimal berada pada keseimbangan antara manfaat pajak dari hutang dan biaya yang berkaitan dengan kebangkrutan (Binangkit dan Raharjo, 2014). 


\section{Teory Sinyal MM}

Teori sinyal MM berasumsi bahwa setiap orang baik investor maupun manajer memiliki informasi yang sama tentang prospek suatu perusahaan. Hal ini disebut sebagai informasi simetris.Hal ini disebut sebagai informasi asimetris. namun pada kenyataanya manajer sering kali memiliki informasi yang lebih baik dibandingkan investor luar. (Brigham dan Houston, 2011).

\section{Teori Modigliani dan Miller (M\&M)}

Modigliani - Miller (1958) menyatakan bahwa nilai suatu perusahaan seharusnya tidak dipengaruhi oleh struktur modalnya. Atau dengan kata lain hasil yang diperoleh MM menunjukan bahwa bagaimana cara perusahaan mendanai operasinya tidak memiliki pengaruh, sehingga struktur modal adalah sesuatu yang tidak relevan.

\section{Faktor-Faktor yang Mempengaruhi Struktur Modal}

Menurut Brigham dan Houston (2011: 188) Faktor-faktor yang mempengaruhi struktur modal adalah: (1) stabilitas penjualan, (2) struktur asset, (3) leverage operasi, (4) Tingkat pertumbuhan, (5) profitabilitas, (6) Pajak, (7) Kendali, (8) Sikap manajemen, (9) Sikap pemberi pinjaman dan lembaga pemeringkat, (10) Kondisi pasar, (11) Kondisi internal perusahaan, (12) Fleksibilitas keuangan.

\section{Profitabilitas}

Menurut Brigham dan Houston (2011: 189) menyatakan bahwa "tingkat pengembalian yang tinggi memungkinkan perusahaan-perusahaan tersebut melakukan sebagian besar pendanaannya melalui dana yang dihasilkan secara internal"

Profitabilitas merupakan faktor yang dipertimbangkan dalam menentukan struktur modal perusahaan. Hal ini dikarenakan perusahaan yang memiliki profitabilitas tinggi cenderung menggunakan utang yang relatif kecil karena laba ditahan yang tinggi sudah memadai untuk membiayai sebagian besar kebutuhan pendanaan (Zuliani dan Asyik, 2014)

\section{Pertumbuhan Perusahaan}

Setiap perusahaan berusaha mencapai pertumbuhan yang tinggi setiap tahunnya karena pertumbuhan perusahaan memberikan gambaran perkembangan perusahaan yang terjadi (Fauzi dan Suhadak, 2015). Menurut Brigham dan Houston (2011:189) menyatakan bahwa perusahaan yang memiliki pertumbuhan lebih cepat harus lebih mengandalkan diri pada modal eksternal.

\section{Pertumbuhan Penjualan}

Pertumbuhan penjualan merupakan perubahan kenaikan ataupun penurunan penjualan dari tahun ke tahun yang dapat dilihat pada laporan labarugi perusahaan. Perusahaan yang baik dapat dilihat dari penjualannya dari tahun ke tahun yang terus mengalami kenaikan, hal tersebut berimbas pada meningkatnya keuntungan perusahaan sehingga pendanaan internal perusahaan juga meningkat.

Sedangkan menurut Rudianto (2009:56) menyatakan bahwa pertumbuhan penjualan merupakan volume penjualan pada tahun-tahun mendatang, berdasarkan data pertumbuhan volume penjualan historis.

\section{Struktur Aset}

"Perusahaan yang asetnya memadai untuk digunakan sebagai jaminan pinjaman cenderung akan cukup banyak menggunakan utang". (Brigham dan Houston, 2011:188) sedangkan menurut Zuliani dan Ayik (2014) "Struktur aset dalam perusahaan mempunyai pengaruh terhadap sumber-sumber pembiayaan".

\section{Pengembangan Hipotesis} Hubungan Profitabilitas dengan Struktur Modal

Perusahaan akan lebih memilih laba ditahan untuk membiayai sebagian kebutuhan pendanaan. Semakin tinggi ROA, maka semakin kecil utang di dalam struktur modal perusahaan. Penelitian Kesuma (2009) menunjukkan bahwa profitabilitas secara signifikan berpengaruh positif terhadap struktur modal. Putra dan Kesuma (2013) bahwa variabel profitabilitas secara parsial memiliki pengaruh negatif dan signifikan terhadap struktur modal. Putri (2012) variabel profitabilitas memiliki pengaruh positif namun tidak signifikan terhadap struktur modal.

\section{Hubungan Pertumbuhan Perusahaan dengan Struktur Modal}

Pertumbuhan perusahaan merupakan kemampuan perusahaan untuk meningkatkan ukuran 
perusahaan yang dapat dilihat dari adanya peningkatan aset.Pertumbuhan perusahaan termasuk salah satu faktor yang mempengaruhi struktur modal. Apabila perusahaan ingin melakukan pengembangan usaha, perusahaan akan cenderung menambah jumlah aset untuk menunjang pengembangan usaha.sehingga membutuhkan dana untuk mencapai tujuan tersebut. Penelitian Khariry dan Yusniar (2016) menyatakan bahwa pertumbuhan perusahaan ada pengaruh yang signifikan terhadap struktur modal.

\section{Hubungan Pertumbuhan Penjualan dengan Struktur Modal}

Pertumbuhan penjualan merupakan kemampuan perusahaan untuk meningkatkan tujuan perusahaan dalam meningkatkan kinerja keuangan perusahaan. Pada saat pertumbuhan penjualan meningkat perusahaan akan mengambil utang agar dapat meningkatkan kapasitas produksi yang akan berdampak pada kenaikan penjualannya.Pertumbuhan penjualan termasuk salah satu factor yang mempengaruhi struktur modal.

\section{Hubungan Struktur Aktiva dengan Struktur Modal}

Weston dan Copeland (1997) menyatakan bahwa "perusahaan yang mempunyai aktiva tetap jangka panjang lebih besar, maka perusahaan tersebut akan banyak menggunakan hutang jangka panjang, dengan harapan aktiva tersebut dapat digunakan untuk menutup tagihannya". Penelitian Putri (2012) Struktur Aktiva (Fixed Assets toTotal Assets/FATA) berpengaruh positif dan signifikan terhadap struktur modal (Long Term Debt to Equity Ratio).

\section{Kerangka Pemikiran}

Tujuan perusahaan bisa tercapai salah satunya dengan memenuhi kebutuhan dana untuk operasional perusahaan. Untuk pendanaan tersebut perusahaan harus berusaha menyeimbangkan menggunakan dana yang berasal dari eksternal (hutang) atau dana yang berasal dari jumlah modal sendiri yang tercermin dalam struktur modal perusahaan, perlu diperhitungkan berbagai faktor - faktor yang mempengaruhi struktur modal, yaitu profitabilitas, tingkat pertumbuhan, pertumbuhan penjualan dan struktur asset.

Adapun dalam penelitian ini digambarkan dalam model sebagai berikut :

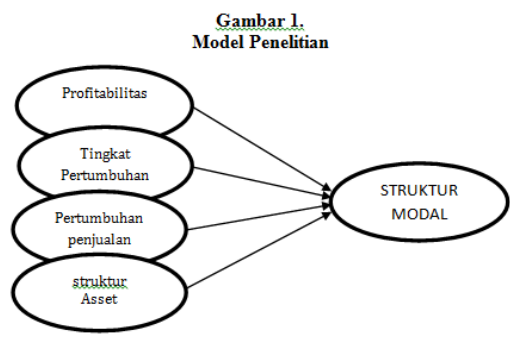

Hipotesis:

1. Secara parsial terdapat pengaruh profitabilitas, pertumbuhan perusahaan, pertumbuhan penjualan, struktur aktiva terhadap struktur modal.

2. Secara bersama-sama terdapat pengaruh profitabilitas, pertumbuhan perusahaan, pertumbuhan penjualan, struktur aktiva terhadap struktur modal.

\section{Metode Penelitian}

\section{Jenis Penelitian}

jenis penelitian ini adalah penelitian kuantitatif yang menggunakan data sekunder diambil dari Bursa Efek Indonesia berupa laporan keuangan yang listing dari tahun 2012 sampai dengan tahun 2014.

\section{Objek Penelitian}

Penelitian ini dilakukan di Bursa Efek Indonesia (BEI). Pemilihan perusahan-perusahan yang go public di bursa efek indonesia sebagai obyek penelitian ini didasarkan pada alasan bahwa:

a. Perusahaan di BEI mempunyai kewajiban untuk menyampaikan laporan keuangan dan laporan tahunan perusahaan.

b. Laporan keaungan perusahaan yang terdaftar di BEI sudah diaudit sehingga laporan keuanganya bisa dipercaya kebenaranya.

c. Kemudahan mengakses data dan informasi.

\section{Penentuan Populasi dan Sampel}

Populasi dalam penelitian ini adalah perusahan-perusahaan sector industry barang konsumsi yang terdaftar di BEI (Bursa Efek Indonesia) periode tahun 2012 sampai dengan 2014, pengambilan sampel yang akan diuji dalam penelitian ini menggunakan metode purposive sampling yaitu metode pemilihan sampel dengan beberapa kriteria sebagai berikut: 
1. Merupakan perusahaan sektor industri barang konsumsi yang terdaftar di BEI sejak tahun 2012 sampai dengan 2014.

2. Menerbitkan terus menerus laporan keuangan yang telah diaudit per 31 Desember dalam periode penelitian.

\section{Pengumpulan Data}

Data yang digunakan dalam penelitian ini adalah data sekunder berupa data laporan keuangan perusahan-perusahaan sector industry barang konsumsi yang terdaftar di Bursa Efek Indonesia mulai tahun 2012 sampai dengan 2014. Sumber data diperoleh melalui sumber database Laporan keuangan di www.idx.co.id .

\section{Struktur Modal}

Struktur modal merupakan perpaduan dari nilai hutang dan nilai modal sendiri yang tercermin pada laporan keuangan. Variabel ini diukur dengan Debt to total asset ratio (DAR) merupakan rasio antara jumlah hutang dengan jumlah aktiva. Artinya seberapa besar aktiva perusahaan yang dibiayai oleh hutang atau seberapa besar hutang. Struktur Modal, ditentukan dengan membandingkan total hutang jangka panjang atas modal sendiri perusahaan (Riyanto, 2001) dengan persamaan sebagai berikut:

debt to total ratio $=$ Total Debt/ Total Aktiva

\section{Pertumbuhan Perusahaan}

Pertumbuhan asset perusahaan dapat diukur dengan menggunakan rasio Asset growth (AG) yang dirumuskan sebagai berikut:

\section{$A G=\frac{\text { total Asset }- \text { total asset } t-1}{\text { totaL asset } t-1}$}

\section{Profitabilitas}

Profitabilitas adalah kemampuan perusahaan untuk memperoleh laba dari kegitan bisnis yang dilakukannya

ROA $=\frac{\text { laba bersih }}{\text { Total aset }}$

\section{Pertumbuhan Penjualan}

Menurut Kesuma (2009) Growth of sales (X1) adalah kenaikan jumlah penjualan dari tahun ke tahun atau dari waktu ke waktu. Cara pengukurannya adalah dengan membandingkan penjualan pada tahun ke $t$ setelah dikurangi penjualan pada periode sebelumnya terhadap penjualan pada periode sebelumnya.

$\mathrm{SG}=\frac{S t-S t-1}{s t-1}$

Keterangan:

$\mathrm{S} 1$ : penjualan pada tahun ke $\mathrm{t}$.

St-1: penjualan pada periode sebelumnya.

\section{Struktur Aktiva}

Struktur Aktiva merupakan rasio antara aktiva tetap dengan aktiva yang dimiliki perusahaan (Husnan, 2002).

$\mathrm{SA}=\frac{\text { Aktiva Tetap }}{\text { Total Aktiva }}$

\section{Teknik Analisis}

Pengujian hipotesis dalam penelitian ini dilakukan dengan menggunakan model regresi linear berganda, dalam analisis regresi tersebut akan diuji pengaruh antara variabel independen (X) terhadap variabel dependen $(\mathrm{Y})$ dengan model persamaan regresi:

$\begin{array}{ll}\text { SM }=\text { b1PR }+ \text { b2PP+b3PJ+b4SA+e. } \\ \text { dimana: } \\ \text { SM } & \text { : Struktur Modal } \\ \text { PR } & \text { : Profitabilitas } \\ \text { PP } & \text { : Pertumbuhan Perusahaan } \\ \text { PJ } & \text { : Pertumbuhan Penjualan } \\ \text { SA } & \text { : Struktur Aktiva } \\ \text { b1,b2,b3,b4 } & \text { : Koefisien regresi } \\ \text { e } & \text { : Nilai standar eror }\end{array}$

Namun sebelumnya akan diuji terlebih dahulu syarat penggunaan regresi linier yang meliputi : Uji Normalitas dan Uji Asumsi Klasik yang meliputi uji multikolenieritas, uji heterokedastisitas, dan uji auto korelasi

\section{Koefisien Determinasi Berganda $\left(\mathbf{R}^{2}\right)$ \\ Untuk mengetahui kontribusi variabel dependen terhadap variasi (naik turunnya) variabel independen maka digunakan koefisien determinasi berganda menggunakan perbandingan antara jumlah kuadrat regresi dengan jumlah kuadrat total.Semakin nilai $\mathrm{R}^{2}$ mendekati 1 maka semakin cocok garis regresi untuk meramalkan variabel tak bebas.}




\section{Pengujian Hipotesis}

Untuk menguji $\mathrm{H}_{1}$, yaitu uji signifikansi variabel bebas ( $\mathrm{x}_{\mathrm{i}}$ ) terhadap variabel terikat $(\mathrm{Y})$, akan dilakukan dengan uji statistik $\mathrm{F}$ untuk melihat pengaruh secara simultan dan uji statistik $t$ untuk melihat pengaruh secara parsial.

\section{Uji F-stat}

Pengujian hipotesis secara simultan adalah:

1. Apabila nilai signifikansi lebih kecil dari pada tingkat toleransi kesalahan sebesar 5\% $(\alpha=0.05)$ maka $\mathrm{H}_{0}$ ditolak dan $\mathrm{H}_{1}$ diterima.

2. Apabila nilai signifikansi lebih besar dari pada tingkat toleransi kesalahan sebesar 5\% $(\alpha=0.05)$ maka $\mathrm{H}_{0}$ diterima dan $\mathrm{H}_{1}$ ditolak.

\section{Uji t}

Pengujian hipotesis secara parsial adalah:

Apabila nilai signifikansi lebih kecil dari pada tingkat toleransi kesalahan sebesar 5\% $(\alpha=0.05)$ maka $\mathrm{H}_{0}$ ditolak dan $\mathrm{H}_{1}$ diterima.

\section{Hasil dan Pembahasan \\ Uji Normalitas}

Berdasarkan hasil uji normalitas menunjukkan bahwa data berada dan tersebar di sekitar garis diagonal yang berarti bahwa data dari penelitian ini dapat dinyatakan telah memenuhi persyaratan normalitas yang diberlakukan.

Adapun uji normalitas dalam penelitian ini dapat dilihat pada gambar berikut ini :

\section{Gambar 2}

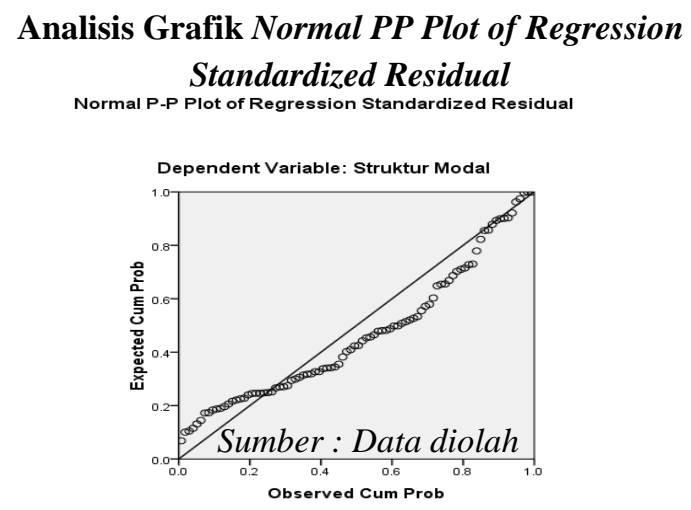

Non-Heteroskedastisitas
Deteksi ada atau tidaknya heteroskedastisitas dapat dilakukan dengan melihat ada tidaknya pola tertentu pada grafik scaterplot (Ghozali, 2009). Uji non-heteroskedastisitas dalam penelitian ini adalah sebagai berikut:

\section{Gambar 3}

\section{Grafik Scatterplot}

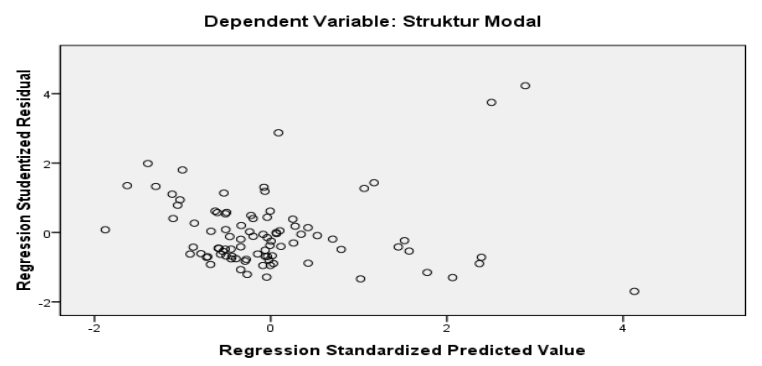

Sumber : Data diolah

Hasil uji scaterplot pada uji statistik memperlihatkan gambar berupa titik-titik yang tersebar secara acak baik di atas maupun di bawah dari angka 0 (nol) pada sumbu Y. Diagram scater plot seperti pada gambar 3 di atas membuktikan bahwa model regresi dari penelitian ini telah terbebas dari masalah heteroskedastisitas.

\begin{tabular}{|c|c|c|c|c|c|c|c|c|}
\hline 帮 & & & & $\begin{array}{l}\text { Tabel 1. } \\
\text { efficien }\end{array}$ & & & & \\
\hline & & $\begin{array}{l}\text { Unstan } \\
\text { Coeffic }\end{array}$ & $\begin{array}{l}\text { rdize } \\
\text { ats }\end{array}$ & $\begin{array}{l}\text { Stand } \\
\text { Coeffi }\end{array}$ & & & $\begin{array}{l}\text { Col } \\
\text { Sta }\end{array}$ & $\begin{array}{l}\text { earity } \\
\text { ics }\end{array}$ \\
\hline & & B & Std. & r Beta & $\mathbf{T}$ & Sig. & $\begin{array}{l}\text { Tol } \\
\text { ce }\end{array}$ & VIF \\
\hline 1 & (Constant) & .373 & .042 & & 8.835 & .000 & & \\
\hline & Profitabilitas & -.252 & .154 & -.161 & -1.641 & .104 & .874 & 1.144 \\
\hline & $\begin{array}{l}\text { Pertumbuhan } \\
\text { Perusahaan }\end{array}$ & .006 & .001 & .489 & 5.088 & .000 & .914 & 1.094 \\
\hline & $\begin{array}{l}\text { Pertumbuhan } \\
\text { Penjualan }\end{array}$ & -.003 & .007 & -.037 & -.373 & .710 & .845 & 1.184 \\
\hline & Struktur Aktiva & .001 & .001 & .078 & .844 & .401 & .990 & 1.010 \\
\hline
\end{tabular}

\section{Non-Autokorelasi}

Untuk menguji ada atau tidaknya auto korelasi dapat dideteksi dengan melihat nilai DurbinWatson, yang ditunjukkan pada tabel 2 di bawah ini.

\begin{tabular}{ccccc}
\multicolumn{5}{c}{ Hasil Uji Determinasi } \\
\hline Model & R & R Square & $\begin{array}{c}\text { Adjusted R } \\
\text { Square }\end{array}$ & $\begin{array}{c}\text { Durbin- } \\
\text { Watson }\end{array}$ \\
\hline 1 & $.531^{\mathbf{a}}$ & .282 & .248 & 1.942 \\
\hline Sumber $:$ Data diolah &
\end{tabular}

Berdasarkan tabel 2 di atas nilai DurbinWatson untuk semua model berada di atas -2 dan berada di bawah 2 yang berarti sesuai pendapat dari Santoso (2001) bahwa semua model regresi yang 
diajukan dalam penelitian ini terlepas dari masalah auto korelasi.

\section{Persamaan Regresi}

Persamaan regresi dalam penelitian ini dari tabel 1 adalah:

$Y=0,373-0,252 X 1+0,006 X_{2}-0.003 X_{3}+0,485 X_{4}$

Di mana:

$\mathrm{Y}=$ Struktur Modal

$\mathrm{X}_{1}=$ Profitabilitas

$\mathrm{X}_{2}=$ Pertumbuhan perusahaan (growth)

$\mathrm{X}_{3}=$ Pertumbuhan penjualan

$\mathrm{X}_{4}=$ struktur aktivaUji Heteroskedastisitas

Tabel 3

Uji F

ANOVA $^{b}$

\begin{tabular}{llccccc}
\hline Model & & Sum of Squares & df & Mean Square & F & Sig. \\
\hline \multirow{3}{*}{1} & Regression & 1.883 & 4 & .471 & 8.338 & $.000^{3}$ \\
\cline { 2 - 7 } & Residual & 4.798 & 85 & .056 & & \\
\cline { 2 - 7 } & Total & 6.680 & 89 & & & \\
\hline
\end{tabular}

a. Predictors: (Constant), Struktur Aktiva, Pertumbuhan Penjualan, Pertumbuhan Perusahaan, Profitabilitas

b. Dependent Variable: Struktur Modal

Sumber : Datadiolah

Berdasarkan hasil uji Anova atau F Test pada Tabel 3 diperoleh bahwa $F$ hitung adalah 8.338 dengan tingkat signifikansi 0,000 . Karena probabilitas $(0,000)$ lebih kecil dari 0,05, maka model regresi bisa dipakai untuk memprediksi struktur modal. Dengan kata lain, Profitabilitas, pertumbuhan penjualan, pertumbuhan perusahaan dan struktur aktiva secara bersama-sama berpengaruh signifikan terhadap struktur modal.

Berdasarkan Tabel 1 di atas, maka dapat diketahui bahwa terdapat satu variabel yang secara parsial berpengaruh terhadap strukutur modal yaitu pertumbuhan perusahaan. Hal ini dapat diketahui dari tingkat signifikansivariabel ini dibawah tingkat toleransi kesalahan 5\% $(0,05)$ yaitu 0,000. Artinya secara parsial variabel-variabel pertumbuahan perusahaan dapat digunakan untuk memprediksikan struktur modal perusahaan.

Adapun variabel-variabel profitabilitas, pertumbuhan penjualan dan struktur aktiva secara parsial berpengaruh tidak signifikan terhadap struktur modal. Hal ini karena tingkat signifikansi variabel tersebut lebih besar dari pada toleransi tingkat kesalahan $5 \%(0,05)$ yaitu profitabilitas sebesar 0,104 , pertumbuhan penjualansebesar 0,710 dan struktur aktiva sebesar 0,401Artinya secara parsial variabelvariabel pertumbuhan dan ukuran perusahaan tidak dapat digunakan untuk memprediksikan struktur modal perusahaan.

Gambaran tentang koefisien regresi dari masingmasing variabel independen yang digunakan dalam penelitian adalah:

a. Variabel XI (Profitabilitas)

Secara parsial variabel XI (profitabilitas) memiliki nilai probabilitas (siginifikansi) 0,104 lebih besar dari toleransi kesalahan $(\alpha)$ yang diberlakukan yaitu sebesar $5 \%(0,05)$ dan nilai T Hitung < T Tabel yaitu $-1.641<1.988$ sehingga bisa diartikan parsial variabel X1 (profitabilitas) tidak berpengaruh signifikan terhadap struktur modal.Artinya perusahaan Hasil penelitian sejalan dengan penelitian yang dilakukan oleh putri (2012). Penelitian berbeda dengan Khariry dan Yusniar(2016), Kesuma (2009), Nadziraah, Yudiaatmaja dan Cipta (2016), Prabansari dan Kusuma (2005), Firnanti (2011) yang menyatakan bahwa profitabilitas berpengaruh signifikan terhadap struktur modal. Hasil penelitian yang tidak signifikan ini disebabkan karena adanya penurunan jumlah laba beberapa perusahaan pada setiap tahunnya.

b. Variabel X2 (Pertumbuhan Perusahaan)

Secara parsial variable X2 (Pertumbuhan Perusahaan) memiliki nilai probabilitas (siginifikansi) 0,000 lebih kecil dari toleransi kesalahan $(\alpha)$ yang diberlakukan yaitu sebesar $5 \%(0,05)$ dan nilai $\mathrm{T}$ Hitung $>\mathrm{T}$ Tabel yaitu $5.088>1.988$ artinya secara parsial variabel X2 (Pertumbuhan Perusahaan) berpengaruh signifikan terhadap struktur modal.Artinya peningkatan asset didukung dengan meningkatnya hutang. Tingkat pertumbuhan yang tinggi akan meningkatkan jumlah aktiva yang dibutuhkan sehingga memerlukan dana yang lebih banyak untuk memenuhi aktiva tersebut. Hasil penelitian sesuai dengan teori pecking order perusahaan dalam pertumbuhan tinggi akan membutuhkan dana eksternal. Hasil penelitian sejalan dengan penelitian yang dilakukan oleh Khariry dan Yusniar (2016), Ticoalu (2013) Tetapi berbeda dengan hasil penelitian Zuliani 
dan Asyik (2014), Widayanti, Triaryati dan Abundanti (2016), Indahningrum dan Handayani (2009) yang menyatakan bahwa pertumbuhan perusahaan tidak berpengaruh secara signifikan.

c. Variabel X3 (Pertumbuhan Penjualan)

Secara parsial variabel X3 (Pertumbuhan Penjualan) memiliki nilai probabilitas (siginifikansi) 0,710 lebih besar dari toleransi kesalahan $(\alpha)$ yang diberlakukan yaitu sebesar $5 \%(0,05)$ dan nilai $\mathrm{T}$ Hitung < T Tabel yaitu $0.373<1.988$ artinya secara parsial variabel X3 (Pertumbuhan Penjualan) tidak berpengaruh signifikan terhadap struktur modal. Hasil penelitian sejalan dengan penelitian yang dilakukan oleh Khariry dan Yusniar (2016), Zuliani dan Asyik (2014), Pradana , Fachrurrozie dan Kiswanto (2013), yang menyatakan bahwa pertumbuhan penjualan tidak berpengaruh secara signifikan. Tetapi berbeda dengan hasil penelitian Supriyanto dan Falikhatun (2008) menyatakan bahwa pertumbuhan penjualan berpengaruh secara signifikan.

d. Variabel X4 (Struktur Aktiva).

Secara parsial variable X4 (Struktur Aktiva) memiliki nilai probabilitas (siginifikansi) 0,401 lebih besar dari toleransi kesalahan $(\alpha)$ yang diberlakukan yaitu sebesar 5\% $(0,05)$ dan nilai $\mathrm{T}$ Hitung < T Tabel yaitu $0.844<1.988$ artinya secara parsial variabel X4 (Struktur Aktiva) tidak berpengaruh signifikan terhadap struktur modal.Artinya tidak semua perusahaan menggunakan aktiva untuk jaminan hutang.Hasil penelitian sejalan dengan penelitian yang dilakukan oleh Pradana, Fachrurrozie dan Kiswanto (2013) tetapi berbeda dengan hasil penelitian Liem, Murhadi, Sutejo (2013) yang menyatakan bahwa struktur aktiva berpengruh positif terhadap struktur modal.

\section{Simpular}

\section{Simpulan}

1. Profitabilitas, pertumbuhan penjualan, pertumbuhan perusahaan dan struktur aktiva secara bersama-sama berpengaruh signifikan terhadap struktur modal.

2. Secara parsial pertumbuhan perusahaan berpengaruh secara signifikan terhadap struktur modal sedangkan Pertumbuhan penjualan, profitabilitas dan struktur aktiva tidak berpengaruh secara ssignifikan terhadap struktur modal.

\section{Saran}

a. Penelitian ini dilakukan dengan menggunakan data tahun 2012-2014, sehingga untuk tahun tahun mendatang, hasil penelitian ini masih perlu diuji kembali.

b. Untuk penelitian selanjutnya sebaiknya dapat menggunakan jumlah populasi yang lebih luas dengan menggunakan seluruh perusahaan yang terdaftar pada Bursa Efek Indonesia.

\section{Daftar Pustaka}

[1] Amiriyah dan Andayani. 2014. Pengaruh Kinerja Keuangan, Ukuran Perusahaan dan Resiko Bisnis Terhadap Struktur Modal. Jurnal Ilmu dan Riset. Vol 3 no 1.

[2] Brigham, Eugene F. dan Joel F. Houston. 2011. Dasar-dasar Manajemen Keuangan. Edisi 11 Buku 2. Jakarta : Salemba Empat.

[3] Fauzi, Mohommad Nur dan Suhadak. 2015. Pengaruh Kebijakan Deviden dan Pertumbuhan Perusahaan Terhadap Struktur Modal dan Profitabilitas. Jurnal Administrasi Bisnis . Vol 24 no 1.

[4] Ghozali, Imam. 2011. Aplikasi Analisis Multivariate dengan Program IBM SPSS. Semarang. Badan Penerbit Universitas Diponegoro.

[5] Indahningrum, Rizka Putri dan Handayani, Ratih. 2009. Pengaruh Kepemilikan Manajerial, Kepemilikan Institusional, Dividen, Pertumbuhan Perusahaan, Free Cash Flow dan Profitabilitas Terhadap Kebijakan Hutang Perusahaan. Jurnal Bisnis dan Akuntansi . Vol. 11, No. 3.

[6] Khariry, Mukhlan dan Yusniar, Meina Wulansari. 2016. Faktor-Faktor Yang Mempengaruhi Struktur Modal (Studi kasus pada perusahaan Manufaktur yang terdaftar di Bursa Efek Indonesia periode 2011-2014. Jurnal wawasan Manajemen. Vol 4 no 2.

[7] Liem, Jemmi Halim,.Murhadi, Warner R. dan Sutejo, Bertha Silvia. 2013. Faktor-Faktor Yang 
Mempengaruhi Struktur Modal Pada Industri Consumer goods yang terdaftar di Bursa Efek Indonesia periode 2007-2011. Jurnal Ilmiah Mahasiswa Universitas Surabaya. Vol 2 no 1.

[8] Kesuma, Ali. 2009. Analisis Faktor Yang Mempengaruhi Struktu Modal Serta Pengaruhnya Terhadap Harga Saham Perusahaan Real Estate yang Go Public di Bursa Efek Indonesia. Jurnal Manajemen dan Kewirausahaan. Vol 1 no 1.

[9] Munawir, S. 2004. Analisis Laporan Keuangan. Yogyakarta : Penerbit Liberty.

[10] Nadzirah, Yudiaatmaja Fridayana dan Cipta Wayan.2016. Pengaruh Ukuran Perusahaan dan Profitaabilitas Terhadap Struktur Modal. EJournal Bisma Universitas Pendidikan Ganesha. Volume 4.

[11] Putra, Dwi Ema dan Kesuma, I Ketut Wijaya. 2012. Pengaruh Profitabilitas, Likuiditas, Ukuran, Pertumbuhan terhadap Struktur Modal Industri Otomotif yang terdaftar di Bursa Efek Indonesia. Jurnal Ekonomi. Bali : Universitas Udayana.

[12] Putri, Meidera Elsa Dwi. 2012. Pengaruh Profitabilitas, Struktur Aktiva dan Ukuran Perusahaan terhadap Struktur Modal pada Perusahaan Manufaktur Sektor Industri Makanan dan Minuman yang terdaftar di Bursa Efek Indonesia. Jurnal Manajemen. Vol. 01, No.01. Universitas Negeri Padang.

[13] Pradana, Herdiawan Rudi, Fachrurrozie dan Kiswanto. 2013. Pengaruh Risiko Bisnis, Struktur Aset, Ukuran dan Pertumbuhan Penjualan terhadap Struktur Modal. Accounting Analysis Journal. Vol 2 No 4.

[14] Riyanto, Bambang. 2001. Dasar-dasar Pembelanjaan Perusahaan. Edisi 4. Yogyakarta : Bagian Penerbitan FE.

[15] Rudianto. (2009). Akuntansi Manajemen.Grasindo. Yogyakarta.

[16] Santoso, Singgih. 2004. Mengolah Data Statistik Secara Profesional. Jakarta : PT. Elex media Komputindo.

[17] Supriyanto, Eko dan Falikhatun. 2008. Pengaruh Tangibility, Pertumbuhan Penjualan, Ukuran Perusahaan Terhadap Struktur Keuangan. Jurnal Bisnis dan Akuntansi . Vol 10 No. 1.
[18] Ticoalu, Raiben Meldrick Andrew. 2013. Faktor-Faktor yang mempengaruhi Struktur Modal Pada Perusahaan di Sektor Agriculture Yang Terdaftar di Bursa Efek Indonesia 20072009. Jurnal Ilmiah Mahasiswa University Surabaya. Vol 2 no 2.

[19] Wald, John K. 1999. How Firm Characteristics Affect Capital Structure: An International Comparison. The Journal of Financial Research. Vol. XXII, NO.2 Pages 161-18.

[20] Weston, J. Fred dan Copeland, Thomas.1997. Manajemen Keuangan. Jilid 2 . Edisi 9. Binarupa Aksara.

[21] Widayanti, Luh Putu. Nyoman Triaryati, dan Nyoman Abundanti. 2016. Pengaruh Profitabilitas, Tingkat Pertumbuhan Perusahaan, Likuiditas, Dan Pajak Terhadap Struktur Modal Pada Sektor Pariwisata. E Jurnal Manajemen Unud, Vol. 5 No 6.

[22] Zuliani, Selly dan Asyik, Nur Fadjrik. 2014. Pengaruh Profitabilitas, Pertumbuhan Penjualan, Struktur Aset dan Tingkat Pertumbuhan Terhadap Struktur Modal. Jurnal Ilmu dan Riset Akuntansi. Vol 3 No 7. 